\title{
Performance of Maize Cultivars under Different Plant Densities
}

\author{
Ranyellson Pires Barbosa ${ }^{1}$; Mirya Grazielle Torres Portela ${ }^{1}$; \\ Raphael Lira Araújo ${ }^{1}$; Disraeli Reis da Rocha² \\ ${ }^{1}$ Student of the Postgraduate Program in Agronomy, Federal University of Piaui, Brazil. \\ ${ }^{2}$ Doctor of the plant engineering department of the federal university of Piaui, Brazil
}

\begin{abstract}
The objective of this study was to evaluate the agronomic performance of two maize cultivars for green-maize production, submitted to different plant densities. The experiment was carry out in the experimental field of the Department of Phytotechny of the Center of Agricultural Sciences of the Federal University of Piaui, in a Eutrophic Sandy Neosol, under irrigation conditions. The experimental design was a randomize block, in factorial scheme $5 \times 2$, with five plant densities $\left(40,000,45,000,50,000,55,000\right.$ and 60,000 plants ha $\left.{ }^{-1}\right)$, two cultivars (AG1051 and BM3061) and four repeats. The results showed that the cultivar BM3061 was superior to the cultivar AG1051 in the characteristics number of ears, mass productivity and mass percentage of commercial ears. The densities that promoted the best number yield and productivity of stuffed commercial ears were 45,000; 50,000; 55,000 and 60,000 ha-1 plants. However, the plant densities that promoted the best performances independent of the cultivar used were 45,000, 50,000 and 55,000 plants. $\mathrm{ha}^{-1}$.
\end{abstract}

Keywords: green maize, plant population, AG1051, BM3061

\section{Introduction}

The maize is one of the most important crops for humanity, because of its high yield potential and the various forms of use in food and feed, fresh and in high-tech industry (EMBRAPA, 2010). Approximately 15.08 million hectares are cultivated in Brazil, producing about 78,200 tons of grain, with a $5.2 \mathrm{t}^{-\mathrm{h}^{-1}}$ yield (CONAB, 2015).

The market for maize for human consumption is promising, especially in the Northeast of the country, where the cultivation takes place throughout the year, the grains being used mainly for animal feed (dry grains) and / or human (ears and green grains) (ROCHA et al., 2011).

The recommendation of specific cultivars, combined with photosynthetically active radiation, adequate population density and balanced fertilization are responsible factors for the good yield of green-maize (CALONEGO et al., 2011). For this reason and due to the emergence of new genotypes and management techniques for maize cultivation, several studies have been carry out to determine the best spatial arrangement of maize plants in different regions (KAPPES et al., 2011a).

One of the alternatives to obtain high yields is to choose the appropriate plant densities because, unlike other species of the Poaceae family, maize has low capacity to fill empty spaces, because it rarely grows and has limited leaf expansion capacity and low prolificacy (SANGOI et al. 2011).

Therefore, it is important to conduct research in the search for the best population of plants and spacings that will allow greater yields for maize cultivation, as well as the behavior of genetic material in different regions (SILVA et al., 2014).

besides that, optimum plant density for maize was alter over time as genetic, physiological, biochemical, and anatomical modifications were incorporate into the plants by breeding programs, coupled with changes in crop management, suitable for each region (SERPA et al., 2012). Thus, the identification of the optimal arrangement of plants that results in less competition allows to improve the utilization of available resources for grain growth and yield, promoting better productivity (LIMA et al., 2012)

There is little knowledge about the behavior of maize-green cultivars submitted to different plant densities in the mid-north of Brazil. It is evident in the current literature the absence of works in this sense. Thus, it is necessary to research that can express the behavior of hybrids in different population densities, especially those with more years of use in the market and those younger. Therefore, this study was to evaluate the agronomic performance of two maize cultivars for maize-green production, submitted to different plant densities.

\section{Material And Methods}

The experiment was conduct in the Plant Science Department at the experimental field of Agricultural Sciences Center (ACS), the Federal University of Piauí, located in Teresina, located 5 5'38"S latitude and $42^{\circ} 48^{\prime} 42^{\prime \prime} \mathrm{W}$ of longitude. Teresina has an average annual temperature of $28^{\circ} \mathrm{C}$, average annual photoperiod 12.19 hours/day, average relative humidity of $69,9 \%$ and total annual insolation of 2625 hours (MEDEIROS, 
2006). The soil of the experimental area is classified as Neossolo Sandy Eutrophic, with 5\% clay; $10 \%$ silt and $85 \%$ sand; $\mathrm{pH} 6,1$; field capacity $8 \%$; $0,3 \%$ organic matter; $5 \mathrm{mg} \mathrm{P}_{2} \mathrm{O}_{5} \mathrm{dm}^{-3}$ of soil and $1 \mathrm{mmol}_{\mathrm{c}} \mathrm{dm}^{-3}$ of soil $\mathrm{K}_{2} \mathrm{O}$, according to data from soil analyzes made by the laboratory ACS soils (LASO).

The maize cultivars evaluated were the double hybrid AG1051 and triple hybrid BM3061. The first was made available in the national market by Monsanto, and presents a semi-precocious cycle, slow maturity and versatility of use (grain and green-maize). The second was made available on the market by Biomatrix, presenting early maturity slow cycle and versatility in use (silage and green-maize). We used experimental design of randomized blocks in a factorial $5 \times 2$, where hybrids were submit to five plant densities $(40,000$, $45,000,50,000,55,000$ and 60,000 plants. ha $\left.{ }^{-1}\right)$. Each plot consisted of 3 rows of $5 \mathrm{~m}$ with repeats spaced by $0,6 \mathrm{~m}$. The mineral fertilizer of commercial formula 5-30-15, at the time of planting, was use in an amount equivalent to $400 \mathrm{~kg}$ ha-1, which corresponds to recommendation $20-120-60 \mathrm{~kg}$ ha-1 of NPK.. The mineral fertilizer was distribute at the bottom of the grooves at depths of $0,15 \mathrm{~m}$.

It conducted two covers fertilization area. The first fertilization was performe at 15 days after emergency (DAE) with application of $12 \mathrm{~g}$ per linear meter of ammonium sulfate $(2,4 \mathrm{~g}$ of $\mathrm{N})$ and $6 \mathrm{~g}$ of $\mathrm{KCl}$ $\left(3,6 \mathrm{~g} \mathrm{~K}_{2} \mathrm{O}\right)$. The second fertilizer, urea was use, applying $12 \mathrm{~g}$ per linear meter $(5,4 \mathrm{~g}$ of $\mathrm{N})$, at the beginning of male flowering in all treatments.

The maize sowing was do manually by placing two seeds for planting holes in corresponding arrangements to treatment. Thinning was performed when the plants were in stage V3 to V4 (when they have 3 to 4 fully expanded leaves), leaving one plant per hole. The weed plants were manage by Atrazine and Metolachlor herbicide at the rate of $41 . \mathrm{ha}^{-1}$ of the commercial product and manual weeding done by a spade, twenty days after emergence, in order to manage weed plants not controlled by the herbicides.

Sprays were realize with the pyrethroid insecticide to control the Spodoptera frugiperda at the dose of $1,5 \mathrm{ml}$ of the commercial product per liter of water.

Harvesting was carry out when the maize reached the R3 stage, where the ears reached the maize-green point, that is, when the grain presented $70-80 \%$ humidity, between the milky and pasty stage.

The following characteristics were evaluate in the ears harvested: number of commercial ears stuffed, percentage of commercial ears stuffed, mass of stuffed commercial ears, and percentage of mass of commercial ears stuffed. As commercial stamped spikes were considere those with a size larger than $25 \mathrm{~cm}$ (PAIVA JÚNIOR et al., 2001), with a diameter greater than $5 \mathrm{~cm}$, grenades and free of pests and diseases, appropriate for commercialization. The mass of ears was determine through all the commercial ears of the plot. The percentage of stuffed commercial ears was calculate by the ratio of the weight of stuffed commercial ears to the total weight of stuffed ears. The number of ears was determined by means of the total counting of the commercial ears and the percentage of commercial ears stuffed according to the ratio between the number of commercial ears and the total number of ears.

The data were submit to statistical analysis by the Tukey test at $5 \%$ of probability using the statistical program ASSISTAT.

\section{Results And Discussion}

With the data, we observed that there was interaction between both factors studied, where both the hybrids and the plant densities influenced the number of commercial ears. When compared, in each of the studied densities, the cultivars AG1051 and BM3061 presented a number of commercial ears, similar with 45,000; 50,000 and 55,000 plants per ha-1. In the other densities to cultivar BM3061 was superior according to the comparison test of means. This result disagrees with Rocha et al. (2011) who observe similarities between the two hybrids studied and Paiva et al. (2015) observed that smaller numbers of husked ears in densities 50.000 and 55.000 plants ha ${ }^{-1}$. Smaller values obtained by AG1051 in this assay may be relate to the segregation of this cultivar. With the increase in plant population there was an increase in the number of ears on average up to 50.000 plants per ha ${ }^{-1}$ (Figure 1). Fornasieri Filho (2007) reports that the yield of maize crop rises with increasing plant density to achieve optimum density, from which there is a decrease in productivity. 


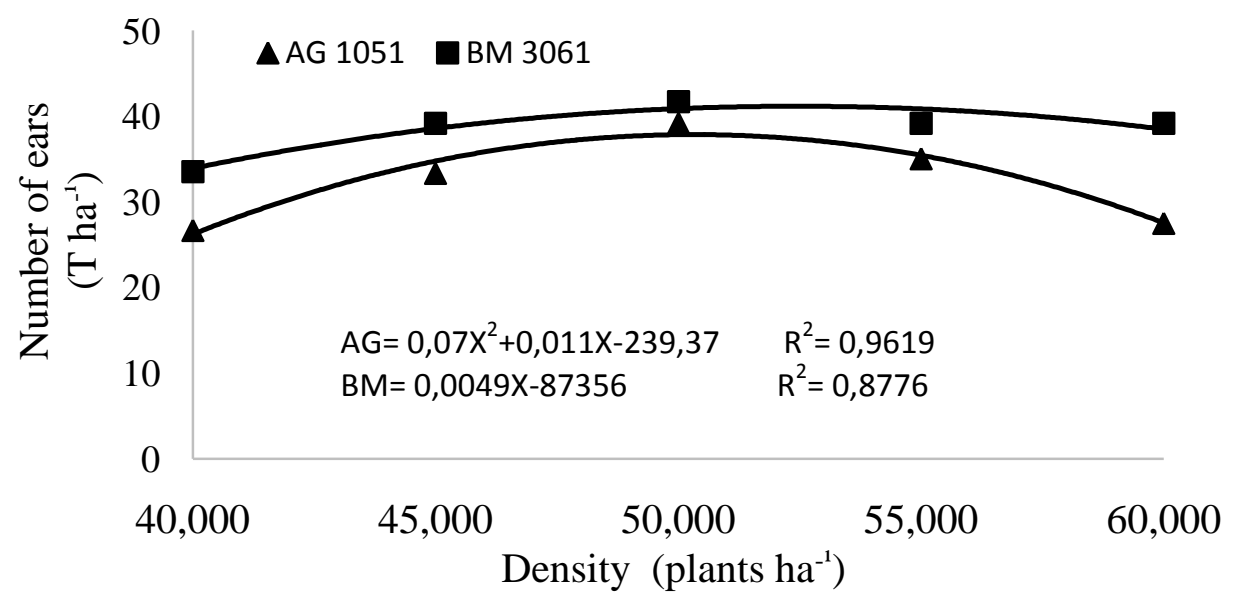

Figure 1. Average number of commercial ears of green-maize stuffed as a result of five plant densities in two green-maize cultivars.

It was observe that there was no interaction among the factors studied to the percentage of the number of commercial ears. Although not observed interactions between treatments, this variable was influence by the plant densities. The BM3061 and AG1051 cultivars were statistically similar to husked percentage of commercial ears ( $p$ 0.05). This result is divergent from those obtained by Rocha (2008), who observed for the cultivar AG1051 and significant higher values than those obtained by cultivating BM3061, and Vieira et al. (2010) reported that reduce the percentage of commercial ears with the population increase.

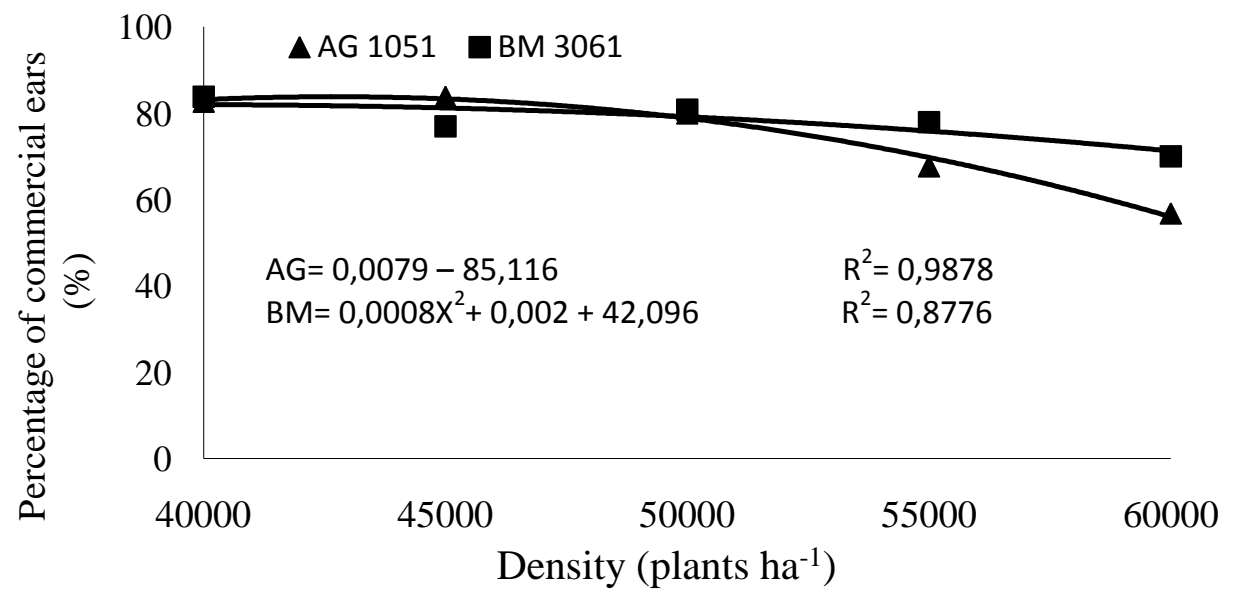

Figure 2. Mean percentage of commercial ears of green husked maize because five plant densities in two green maize cultivars.

It was also note that the percentage of commercial ears decreased with increasing plant density. This variable is influenced by the development of the cob, because it's the ratio between the number of commercial maize and the total number of ears. At low population densities, the competition between plants for water, light and nutrients is small, providing plants the resources needed for filling the grain in more than one cob per plant (KAPPES et al., 2011a). At higher densities the opposite occurs.

The mass yield of commercial maize unhusked per hectare, it was observe that the growing BM3061 obtained increase productivity of commercial maize unhusked when compared with growing AG1051 (p <0.05). Rocha et al (2011), however, reported statistically similar values for these features in the two cultivars.

The density of 50,000 plants ha $^{-1}$ on average between the two cultivars was the one that promoted the highest mass productivity unhusked commercial ears, although statistically similar to densities 45,000; 55,000 and 60,000 plants ha ${ }^{-1}$. Lima et al. (2012) observed increase productivity of two maize hybrids in the density of $55,000 \mathrm{~h}^{-1}$ plants and a significantly reduced while increasing the density of plants per hectare. 
It was also observe that, regardless of the hybrid, the density of 50,000 plants ha- 1 was an increase in productivity of approximately $23 \%$ compared to the lower density and measured about $16.44 \%$ compared to the higher density. Silva et al. (2014) observed that the higher density provided a maize production increased by about $14 \%$ compared to the lower density measured. Comparing the two cultivars in five densities studied statistically similar results in the density of 50,000 plants $\mathrm{ha}^{-1}$. In the other densities were predominant cultivar BM3061. The production of commercial unhusked maize density increases arithmetically 40.000 to 50.000. Decreasing this to 60.000 ha $^{-1}$ (Figure 3). Rocha et al. (2011) also observed that the cultivar AG1051 reached the maximum productivity of green ears in the density of 48,920 plants $\mathrm{ha}^{-1}$. It was also observe that the growing BM3061 responded positively to the increase in population density, since most studied density was 60,000 plants $\mathrm{ha}^{-1}$. Souza et al. (2013) observed an increase in the production of commercial ears in densities from 40,000 plants $\mathrm{ha}^{-1}$ for both hybrids.

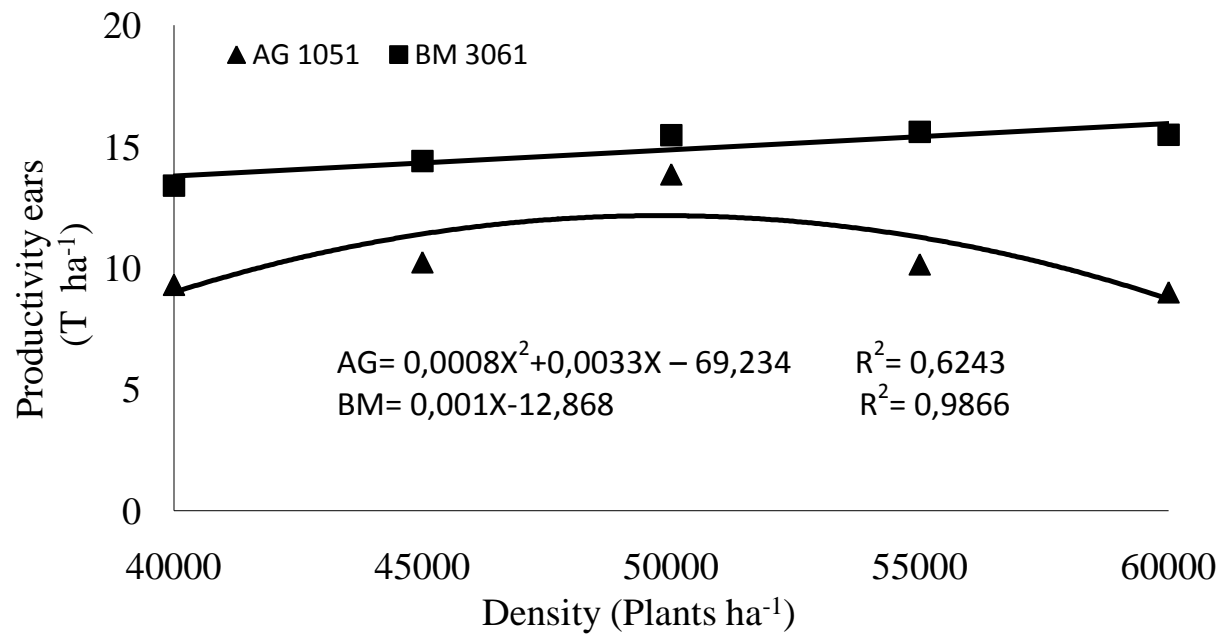

Figure 3. Average productivity of commercial ears of maize obtained from the evaluation of two cultivars submitted to five plant densities.

It was observe for mass percentage of commercial unhusked ears, that this feature was influence by plant populations, the cultivars and there was an interaction between treatments. Cultivar BM3061 showed the highest percentage of unhusked ears, the average of all plant densities. These results are at variance with the results obtained by Rocha et al. (2011), who observed superior results with AG1051 for this feature. For percentage of commercial unhusked ears the values observed for the cultivar AG1051 were decreasing while increasing the density of plants per hectare. To cultivate BM3061 this variable showed a linear response (Figure 4). The best result was obtained by the density of 40,000 plants ha $^{-1}$, although statistically similar densities to $45,000,50,000$, and 55,000 plants $\mathrm{ha}^{-1}$. The lower yield was obtain in the density 60,000 plants ha ${ }^{-1}$. Grigulo et al. (2011), observed in maize plants at a density of 50,000 plants ha ${ }^{-1}$, mass percentage of $61,49 \%$ in a conventional system.

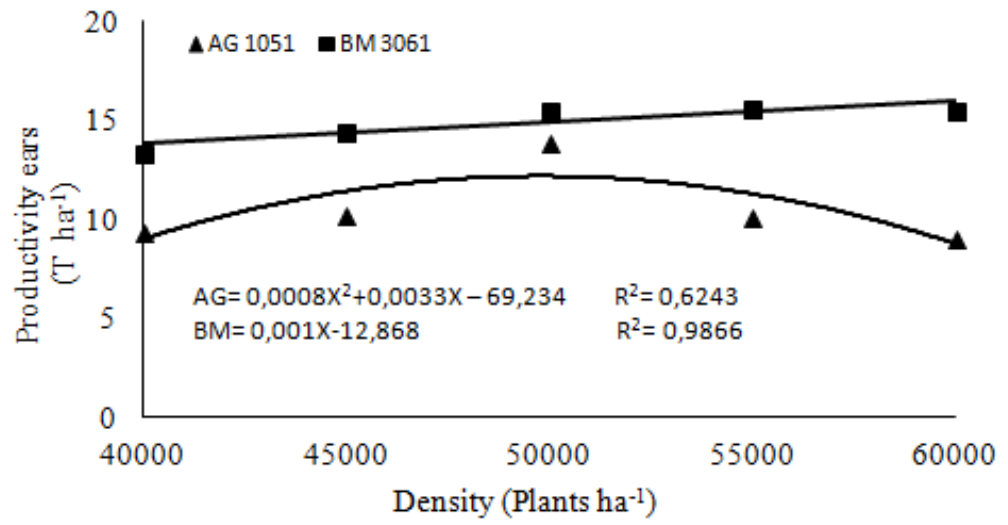

Figure 4. Percentage of unhusked mass commercial maize ears obtained in the evaluation of two cultivars, submitted to five plant densities. 
The lower yield was obtain in the density 60,000 plants $\mathrm{ha}^{-1}$. The percentage of ears is influence by the development of the reproductive organ; it is the ratio between the mass of commercial maize and the total mass of maize. Kappes et al. (2011b) argue that the increase in the number of plants per area, to a limited extent, tends to offset the decrease in the size of the ears, reflecting in mass. For Takasu et al. (2014), the best grain yield are obtained in populations whose prolificacy is close to the unit, large enough ears to not decrease productivity

\section{Conclusions}

The cultivar has BM3061 number of ears per hectare, ears yield per hectare and mass percentage of best maize that the same variables cultivar AG1051. The two cultivars were similar regarding the percentage of commercial ears unhusked. Plant densities that promoted the best performance independent of the cultivar used were 45.000, 50.000 and 55.000 plants $\mathrm{ha}^{-1}$.

\section{References}

[1] ASSISTAT, statistical assistance, beta (2012), developed by the Department by the Department of Agricultural Engineering, the Center for Science and Technology, Federal University of Campina Grande, PB.

[2] CAlOnEGO, J. C.; POLETO, L. C.; DOMINGUES, F. N.; TIRITAN C. S. Productivity and growth in different maize plant arrangements. Agrarian, v. 4, 84-90, 2011.

[3] CONAB. National Company Supply. Monitoring of the Brazilian grain harvest 2014/2015. Brasília: Conab, 2015. 35p

[4] EMBRAPA. Empresa Brasileira de Pesquisa Agropecuária. Cultivation of maize. 4. ed, 2010. Available at <br/htmlsupplies/maize/maizecultivation/growing>. Accessed on June 21, 2015.

[5] FORNASIERI FILHO, D. 2007. Maize Manual. Jaboticabal: FUNEP, 576p.

[6] GRIGULO, A. S. M.; AZEVEDO, V. M.; KRAUSE, W.; AZEVEDO, P. H. Evaluation of the performance of maize genotypes for fresh consumption in Tangara da Serra, Mato Grosso, Brazil. Biosciencia, v. 27(4), 603-608, 2011.

[7] KAPPES C; ANDRADE, J. A. C.; ARF, O.; OLIVEIRA, Â. C.; ARF, M. V.; FERREIRA, J. P. Arrangement of plants for different maize hybrids. Journal of Tropical Agriculture, v. 41, 348-359, $2011 \mathrm{a}$.

[8] KAPPES C; ANDRADE, J. A. C.; ARF, O.; OLIVEIRA, Â. C.; ARF, M. V.; FERREIRA, J. P. Performance of maize hybrids in different spatial arrangements of plants. Bragantia, v. 70, 334-343, $2011 \mathrm{~b}$.

[9] LIMA, C. F.; ARNHOLD, E.; ARAÚJO, B. L.; OLIVEIRA, G. H. F.; OLIVEIRA JUNIOR, E. A. Evaluation of maize hybrids under three population densities in agricultural frontier in Maranhão. Comunicata Scientiae, v.3, 30-34, 2012.

[10] MEDEIROS, R. M. Climatology of the City of Teresina. Teresina: Department of Environment and Natural Resources of the State of Piauí, 2006, 28p.

[11] PAIVA, R. S. A.; PEREIRA JUNIOR, E. B.; ALMEIDA, R. S.; HAFLE, O. M.; OLIVEIRA, F. T. Response Creole maize to different population densities in the soil and weather conditions of the Hinterland Paraibano. Agricultural Research in Semi-Arid, v.11, 120-125, 2015.

[12] PAIVA JUNIOR, M. C .; VON PINE, E. V. R.; RESENDE, S. G. Performance cultivars for production of maize at different times and seeding rates in Lavras - MG. Science and Agrotecnologia, v.25(5), 1235-1247, 2001.

[13] ROCHA, D. R.; FORNASIER FILHO, D.; BARBOSA, J. C. Effect of plant density on commercial green ears yield of maize cultivars. Brazilian Horticulture, v. 29(3), 392-397 2011.

[14] ROCHA, D. R. 2008. Performance green maize cultivars submitted different plant populations in irrigation conditions. Doctoral Test in Agronomy - Paulista State University, Jaboticabal, Brasil. 89 f.

[15] SANGOI, L.; SCHWEITZER, C.; SILVA, P. G. F.; SCHMITT, A.; VARGAS, V. P.; HOUSE, R. T.; SOUZA, C. A. Tillering, leaf area and maize yield under different spatial arrangements. Brazilian Agricultural Research, V. 46(6), 609-616, 2011.

[16] SERPA, M. S.; SILVA, P. R. F.; SANGOI, L.; VIEIRA, V. M.; MARCHESI, D. R. Density plants sown maize hybrids in late winter in irrigated and dryland environments. Brazilian Agricultural Research, V. 47(4), 541-549. 2012.

[17] SILVA, A. da F.; SCHONINGER, E. L.; CAIONE, G.; KUFFEL, C.; CARVALHO, M. A. C. Productivity of maize hybrids in relation to spacing and plant population under conventional tillage. Journal of Maize and Sorghum, v.13(2), 162-173, 2014.

[18] SOUZA, R. S.; VIDIGAL FILHO, P. S.; SCAPIM, C. A.; MARQUES, O. J.; QUEIROZ, D. C.; OKUMURA, R. S.; RECHE, D. L.; CORTINOVE, V. B. Yield and quality of sweet maize in different plant populations. Agricultural Sciences, v. 34(3), 995-1010. 2013.

[19] TAKASU, A. T.; RODRIGUES, R. A. F.; GOES, R. J ; HAGA, K. I.; ARF, O.; GITTI, D. C. Characteristics of maize agronomic depending on soil preparation and spatial arrangement of plants. Agrarian. v.7(26),485-495, 2014

[20] VIEIRA, M. A.; CAMARGO, M. K.; DAROS, E.; ZAGONEL, J.; KOEHLER, H. S. Cultivars of maize and plant population that affect the productivity of green ears. Acta Scientiarum Agronomy, v. 32(1), 81-86, 2010. 